\title{
Text and Art Acknowledgments
}

\section{se}

The following was provided by Jan Thunholm: Cover illustration, Aeneas and Turnus: The Final Duel.

The following was provided by the Vatican Museum, with special thanks to Paolo Liverani, Director of the Vatican Museum, and to Padre Raffaele Farina, Prefetto della Biblioteca Apostolica Vaticana:

Figure I.I: Aeneas amidst the Storm. From the fifth-century Codex Vergilianus Romanus. Vatican Museum.

The following were provided by Art Resource, in cooperation with the Museo Nazionale, Naples:

Figure 4.I: Medea Meditating on Killing Her Children. Pompeian Fresco. Museo Archeologico Nazionale, Naples.

Figure 4.2: Phaedra and Maid Servant. Pompeian Fresco. Museo Archeologico Nazionale, Naples.

Figure 5.I: Theseus Having Slain the Minotaur. Pompeian Fresco. Museo Archeologico Nazionale, Naples.

The following was provided by Dr. Bettina Bergmann from her personal collection:

Figure 4.3: Helen Embarking. Fresco from the House of the Tragic Poet. Museo Archeologico Nazionale, Naples. 
The following was provided by Art Resource, in cooperation with the Berlin Staatlandes Museum:

Figure 4.4: Helen in Her Boudoir. Red-figured Attic drinking cup (kylix) from Nola, 450-440 в . Side B. Berlin Staatlandes Museum. Photo: Johannes Laurentius.

All Latin citations of Virgil are taken from the edition of R. A. B. Mynors, ed., P. Vergili Maronis Opera (Oxford, I969). Used by permission of Oxford University Press.

All English translations of Virgil are those of Allen Mandelbaum, tr., The Aeneid of Virgil (New York, I97I; rpt. I98I). Used by permission of Bantam Books, a division of Random House, Inc. 